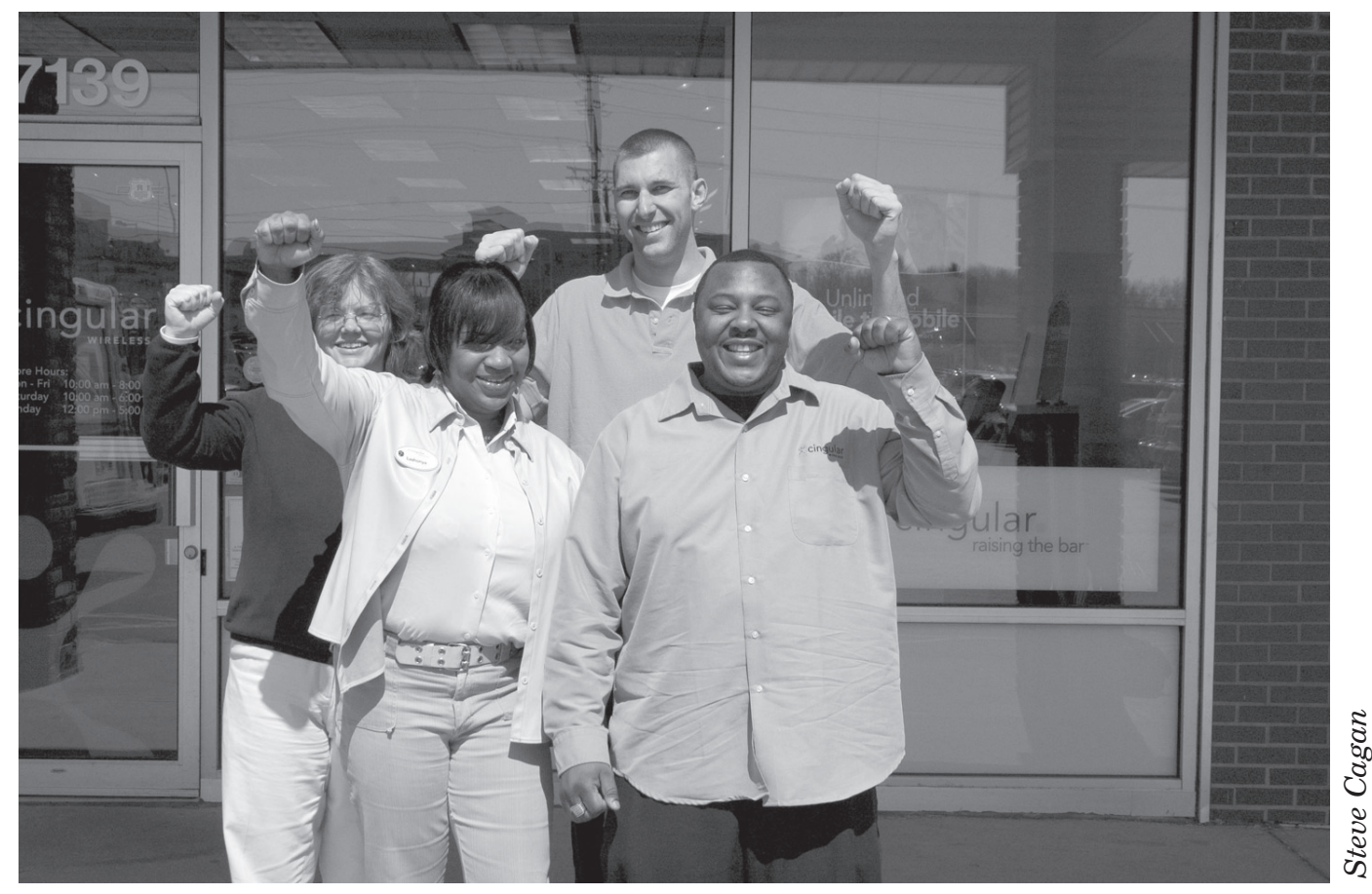

Some 18,000 workers at AT\&T's wireless division (formerly Cingular) have organized with CWA since 2005, including these retail store workers in Ohio. Nationwide, more than 40,000 workers at the company have organized with CWA under the union's neutrality and card check agreement. 


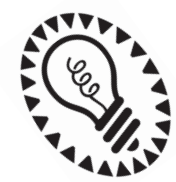

By Richard W. Hurd

NEUTRALITY

AGREEMENTS

\section{Innovative, Controversial, and Labor's Hope for the Future}

OVER THE PAST TEN YEARS THERE HAS BEEN A NOTABLE SHIFT IN UNION ORGANIZING strategies. Once the exception, organizing conducted under the umbrella of negotiated neutrality agreements has become the preferred method in the drive to reverse decline and build union density. This approach allows unions to avoid

the pitfalls of traditional organizing conducted under the National Labor Relations Board (NLRB) framework, which enables employers' aggressive resistance to unionization. Typically, management's anti-union campaigns include mandatory captive audience meetings where the employer condemns the union, one-on-one meetings with supervisors where workers are grilled regarding their union sentiments, firing of selected active union supporters, and legal delays. Instead, if unions are able to secure a binding commitment from the employer to remain neutral, organizing is relatively straightforward and in most cases the union is able to win majority support and bargaining rights.

Pursuit of employer neutrality and the closely associated card check route to certification, where the union is recognized with a majority of workers signing union cards, are not confined to the realm of actual organizing campaigns. Proposed changes in labor law to endorse this approach have elevated neutrality

A shorter version of this paper appears as "The Origins, Effectiveness and Future of Neutrality Agreements," in Perspectives on Work, Fall 2007. Portions of that paper are replicated here with the permission of the editor.

$$
\begin{gathered}
\text { New Labor Forum 17(1): } 35-45 \text {, Spring } 2008 \\
\text { Copyright } \odot \text { Joseph S. Murphy Institute, CUNY } \\
\text { ISSN: } 1095-7960 / 08 \text { print } \\
\text { DOI:10.1080/1095760701834316 }
\end{gathered}
$$


to the top of organized labor's list of political priorities. The spread of neutrality agreements and labor's strong push to amend the law have been spurred by notable cases of organizing success. But this success has invited scrutiny, and attacks from the Right and the Left. For example, legitimate questions have been raised about the topdown nature of some specific Service Employees International Union (SEIU) neutrality agreements. A careful look at the criticisms aimed at SEIU raises more general questions about the wisdom of those neutrality-based organizing campaigns that neither engage workers in struggle nor build union solidarity.

In spite of the criticisms, there can be little doubt that labor's campaigns to achieve and enforce neutrality agreements offer hope that the long-term decline in union density actually can be reversed. A high-profile example of a strategic blend of bargaining and organizing demonstrates the potential of this approach.

\section{HOTEL WORKERS RISING: BUILDING LEVERAGE TO SECURE NEUTRALITY}

N 2006, UNITE-HERE's Hotel Workers

Rising (HWR) campaign drew the public's attention to the health and safety concerns of housekeepers, kitchen workers, and other "back of the house" employees in first-class hotels operated by Hyatt, Hilton, Intercontinental, Marriott, and Starwood. The union's report, Creating Luxury, Enduring Pain, highlighted the trend toward larger beds and multiple oversized pillows and its association with a notable rise in work-related injuries among members of the housekeeping staff. To make its case, UNITE-
HERE used the employers' own Occupational Safety and Health Administration (OSHA) reports, which revealed an annual workplace injury rate of 10.4 percent for housekeepers

\section{Labor's campaigns to achieve and enforce neutrality agreements offer hope that the long-term decline in union density actually can be reversed.}

(Moriarty, 2007: 8). Based on the data, the union publicly exhorted the major hotel chains to agree to changes in work practices, such as increasing the time allotted to clean a room and having housekeepers work in pairs to handle oversized mattresses.

The plight of hotel housekeepers and the HWR campaign became national news because the union had succeeded in securing summer 2006 contract expirations in seven major cities: New York, Chicago, Los Angeles, San Francisco, Boston, Toronto, and Honolulu. The nearly common expiration dates, which had been an objective of union bargaining for several years, were secured through a series of contract fights in individual cities. In several cities the union insisted on shorter contracts (with member support), and in San Francisco members endured a lockout and two years of working without a contract (Sherwyn et. al., 2006). UNITE-HERE's objective in establishing the 2006 expiration dates was to gain greater leverage in negotiations, which would help it 
address workplace concerns such as the health and safety issues. But the foundation of the bargaining strategy was to go beyond wages, benefits, and working conditions and develop leverage that would increase the potential to achieve another high priority: employer agreement to organizing neutrality. The plan succeeded.

In city after city without a strike, UNITEHERE contracts were resolved on terms that met the union's economic and workplace goals; even more important to UNITE-HERE's own institutional health, organizing neutrality was established as the standard in the industry. Both Hilton and Starwood reached national agreements that assured neutrality in luxury and convention hotels in specified markets. In addition, several municipal hotel associations agreed to neutrality language covering both new properties and some existing hotels (Sherwyn et al., 2006). UNITE-HERE estimates that it has added almost 6,000 new members under the agreements (Raynor, 2006).

The 2006 hotel campaign epitomizes the contemporary union practice of bargaining to organize. As was the case with HWR, unions often use a comprehensive strategic approach that includes research, publicity, mobilization, and various forms of leverage to secure key bargaining objectives that address the concerns of current members and facilitate new organizing (Moberg, 2006). In particular, the neutrality agreements secured by UNITE-HERE are by no means unique, but reflect the established consensus that employer commitments to forsake standard union avoidance techniques are essential to organizing success. In order to assess both the viability of these contemporary methods and the validity of lingering criticism, it is important to step back and look at the recent evolution of organizing strategy and at the prospects for legislated changes and future growth.

\section{THE EVOLUTION OF UNION ORGANIZING}

\footnotetext{
A
} S BOTH INDUSTRIAL RELATIONS SCHOLARS AND labor journalists have demonstrated in recent articles, the contemporary paradigm for union organizing in the United States combines employer neutrality and card check recognition (see Moberg, 2006, and Becker et al., 2006). This represents a dramatic shift from the standard NLRB-based organizing framework that prevailed from the passage of the TaftHartley Act in 1947 until at least the late 1980s. During that era, most unions were content to recruit new members and attempt to add new bargaining units under the umbrella of the orderly NLRB representation election procedures. This style actually fit the dominant servicing model of unionism: organizers "sold the union" based on the services it delivered and the contractual improvements it could prom- 
Labor's embrace of the NLRB framework loosened during the 1980s in the face of membership decline and plummeting private sector

\section{The Southwestern Bell} [neutrality] agreement has been particularly successful, with the Communication Workers adding nearly 40,000 members at the company's Cingular Wireless division over the past ten years.

union density. By the early 1990s, a new consensus had emerged in the form of what was referred to as "an organizing model of unionism." The idea was that as flawed as the NLRB election procedures were, unions could overcome their disadvantage with a grassroots model of organizing rooted in building the union rather than selling the union. As argued by prominent advocates of this approach,

[D] espite the intensity of employer opposition, what unions do during organizing campaigns is what matters most... [T] he use of a grassroots, rank-and-file-intensive union building strategy is fundamental in significantly raising the probability of winning (Bronfenbrenner and Juravich, 1998: 33).

Throughout the 1990s, many unions aggressively pursued grassroots organizing. But in spite of some notable successes, union density continued to decline in the private sector. There were two basic problems. First, although most union strategists voiced support for grassroots organizing, few unions fully implemented the rank-and-file unionbuilding tactics central to the new model. Radical organizational change is difficult, and it was particularly hard to win support for the wholesale shift of resources needed to fund grassroots organizing on a scale sufficient to counteract the economic and political forces that were contributing to union decline. Second, employers proved adept at exploiting the weaknesses in (and lax enforcement of) the NLRB union representation process, and increased the intensity and sophistication of their avoidance efforts. This increased the cost of organizing and added to the financial burden on unions as they attempted to maintain campaign activism throughout prolonged organizing fights.

As a strategist from a union that organized under the NLRB in the 1990s describes the current situation, "Now we only use the NLRB when the unit is small, in a single location, and the shop is on fire." Throughout the labor movement, frustration with the NLRB has given birth to a modified approach that has evolved and spread over the past ten years. Employer neutrality agreements have been around in one form or another for decades; for example, construction unions have used top-down organizing to secure work for members based on union agreements with employers, and the United Automobile Workers (UAW) and the United Food and Commercial Workers (UFCW) have negotiated accretion agreements with unionized 
firms that provide for membership growth as new facilities are opened. Some unions have also experimented with neutrality agreements as an adjunct to grassroots organizing since the 1980s (see for example Krump, 1991; Hurd and Rouse, 1990). By the late 1990s, several unions actively engaged in bargaining to organize as part of a national strategy. The Communications Workers of America (CWA) openly advocated this approach, negotiating neutrality clauses with Southwestern Bell (SBC) and AT\&T (Benz, 2002). The SBC agreement has been particularly successful, with the CWA adding nearly 40,000 members at the company's Cingular Wireless division over the past ten years (Acuff, 2007).

Other unions-most visibly SEIU, UNITE, and HERE, but also UAW and the United Steelworkers of America-have utilized corporate campaign techniques from the start of specific organizing initiatives. Their greatest successes have come when the leverage afforded by corporate campaigns made it possible to secure both employer neutrality and card check in order to skip the NLRB election process altogether. By 2001, the AFL-CIO (which had been promoting grassroots organizing and a shift of resources since John Sweeney's election as president in 1995) began "pushing affiliates to avoid the NLRB process when and where possible" (Acuff, 2007). Expanding use and growing consensus established neutrality and card check as the new organizing paradigm for the U.S. labor movement (Moberg, 2006), and today the NLRB has been displaced as "most new members come in through alternative approaches" (Acuff, 2007). The perspective of Teamsters organizing director Jeff Farmer is typical: "In our national organizing strategy, neutrality with card check is always the goal" (Farmer, 2007).

\section{NEUTRALITY AGREEMENTS AND THEIR EFFECTIVENESS}

7

HERE ARE TWO BROAD CATEGORIES OF NEUTRAL-

ity agreements: those that are the product of collective bargaining and those that are negotiated as stand-alone agreements with no connection to existing collective bargaining relationships. The stand-alone agreements are usually secured by unions through the application of corporate campaign pressures, as has been the practice in the SEIU's Justice for Janitors initiative (Baird, 2007). Bargaining to organize may also rely on comprehensive pressure tactics, as was the case in the HWR campaign. Alternatively, neutrality may be secured at the bargaining table as a product of efforts to develop labor-management partnerships, as exemplified by the CWA's agreement with SBC.

Based on mixed experience with the effectiveness of neutrality agreements, unions have, in the past ten years, refined their expectations

\section{Although neutrality has become the standard for private sector organizing, not all agreements are effective.}

of what such agreements should include. Typically, the employer consents to limits on coercive activities such as one-on-one sessions with employees and captive-audience meetings. The 
most effective agreements not only limit negative communications from employers, but also specify that employees will be notified in writing that the employer will remain neutral. The union is usually provided with an accurate list

\section{Expectations that the} EFCA will deliver unions from organizing purgatory may prove to be
overly optimistic.

of workers in the unit and granted some degree of access to the worksite. The employer accepts either card check certification or a timely election conducted by a mutually accepted neutral party. Stand-alone neutrality agreements that accept the standard NLRB contested election framework (technically referred to as stipulated elections) have not been particularly effective and are now avoided. However, in a relatively recent development, the parties may accept a consent election conducted by the NLRB, as is the practice pursued by SEIU's health care division. A final common provision is for arbitration of all disputes under the agreement (Scott, 2004; Eaton and Kriesky, 2001).

Although neutrality has become the standard for private sector organizing, not all agreements are effective. The CWA's apparent victory in securing neutrality in Verizon's wireless division has become instead the source of great acrimony in the form of open resistance from management. The company proved adept at exploiting weaknesses in the contract language, continued to resist organizing, and pre- vailed in several key grievance cases (Patrician and Raab, 2007).

Even in cases where national commitment is secured from an employer, unions often encounter resistance in the workplace from supervisors, who either have not been adequately briefed on the agreement or who become enforcers of the company's continued efforts to resist unionization. Most unions now seek neutrality language that is "strict and straightforward" (Baird, 2007). As described by a lawyer experienced in negotiating and enforcing neutrality agreements, "There is really no neutrality; these are play nice arrangements. There is more access but these usually are nasty little campaigns." Even with neutrality, then, union strategists agree that unions must conduct thorough organizing with effective targeting, assessment, and some degree of grassroots mobilization.

\section{NEUTRALITY, THE EMPLOYEE FREE CHOICE ACT, AND FUTURE PROSPECTS}

\footnotetext{
G
} IVEN THe aCCUMUlating EVIDENCE OF SUCCeSS associated with neutrality agreements and card check, it is not surprising that labor's top political priority is the Employee Free Choice Act (EFCA). As readers of New Labor Forum are undoubtedly aware, the EFCA would augment the NLRB certification process with new limits on employer conduct parallel to those in most neutrality agreements, formalize the process for securing card check certification, and provide for arbitration of first contracts. Although the EFCA failed to pass Congress in 2007 and is unlikely to be enacted without a change in the White House and in the compo- 
sition of the Senate, it is appropriate to speculate on the likely impact of the proposed legislation in light of unions' experiences with voluntarily negotiated neutrality agreements.

There is a widespread presumption among national labor leaders that enactment of the EFCA would cause a reversal in unions' private sector fortunes. Even a cursory review of the Canadian experience under provincial laws that parallel the EFCA indicates that it is wise to be cautious. It is true that private sector union density in Canada stands at 17 percent, more than double the U.S. share of 7.4 percent. However, union density is declining at a similar rate in both countries: there has been a 21 percent relative decline over the past ten years in Canada, compared to a 26 percent relative decline in the United States. As Canadian labor relations scholar Roy Adams points out, because of continued employer resistance "union density and bargaining coverage are falling even in such provinces as Saskatchewan and Quebec that have card-check and first-contract arbitration clauses in effect" (Adams, 2006). Adams concludes that the net impact of the EFCA would be minimal because employer opposition would undoubtedly continue, albeit in an altered form under the new law.

Based on the Canadian experience, then, expectations that the EFCA will deliver unions from organizing purgatory may prove to be overly optimistic. This is really no surprise. Recall that in the 1990s there were many union strategists and analysts (including this author) who believed that the grassroots, union-building model of organizing could overcome the disadvantages of the NLRB representation process. Just as intensifying employer opposition undermined the effectiveness of grassroots organizing, it seems likely that continu- ing employer antagonism will limit the ability of unions to take full advantage of legislated neutrality.

As Orrin Baird of SEIU observes, "Even with the EFCA we will continue doing what we are doing. We will have to whip employers, get employers to accept the union" (Baird, 2007). A national staff member from another union concurs, noting that "even in Canada where the law is better we use corporate campaigns in organizing." American Federation of State, County and Municipal Employees Organizing Director Jim Schmitz adds the following caution: "I hope [the EFCA] doesn't lead to less disciplined organizing" (Schmitz, 2007). In short, even with the EFCA, unions will need to build on the experiences of effective bargaining to organize.

\section{ARE NEUTRALITY AGREEMENTS GOOD FOR WORKERS AND UNIONS?}

VEN THOUGH THERE IS BROAD SUPPORT FOR THE
EFCA, ironically there is also an undercurrent of criticism aimed at unions with aggressive neutrality strategies that are perceived as too top-down in their approach. There is no denying that most neutrality agreements are achieved through top-down methods; the bargaining, corporate campaigns, and political initiatives associated with neutrality are typically controlled by national union leaders and staff. In a clear example of this, a national union organizer recently described to the author a major organizing initiative that is scheduled for kickoff during late 2007 or early 2008. Over a year of preparation has been completed for this multiunion corporate campaign, but as of the end of September 2007 there had been no 
contact at all with the workers who would be targeted.

Although there are top-down aspects of almost every neutrality agreement, SEIU has been subjected to particular scrutiny and criticism. Pacts with nursing home chains in Cali-

\section{Former SEIU executive} board member Gerome Brown warns, "Neutrality agreements negotiated as part of broader political partnerships with employers could

\section{undermine rank-and-file unionism."}

fornia and Washington have been especially controversial. In both cases, the union agreed to push for increased funding that would benefit nursing homes, and in return was guaranteed neutrality in some of the facilities owned by the chains. Criticism of the agreements within SEIU spilled over into public debate with articles in the San Francisco Weekly and the Seattle Times (Smith, 2007; and Thomas 2007). Critics of SEIU within the labor movement were quick to latch onto the articles and distributed them widely.

The negative press coverage may be irrelevant, especially the San Francisco Weekly article, given that paper's libertarian editorial tendencies (Shaw, 2007). But both articles basically echo criticism within the union, and the questions raised by experienced local leaders and organizers are not so easily dismissed. SEIU's United Healthcare Workers West (UHW) questioned two key aspects of the deal with the California nursing homes in an internal report (2007). First, UHW criticized the template contract that served as the basis for bargaining in all new units, decrying especially the failure to involve new members in decisions about negotiating priorities. Second, UHW questioned the terms of the arrangement under which nursing home chains could specify which properties could be organized; only thirty-five of the nursing home chains' 201 previously nonunion facilities achieved representation during the three-year life of the pact. UHW argued that any future agreement should contribute more significantly to the long-term goal of organizing 100 percent of California's nursing homes.

In light of the controversy, SEIU ended its California nursing homes partnership on May 31, 2007 (Brenner, 2007). But similar agreements are in effect in other states, so the internal debate continues. Former SEIU executive board member (and long-time president of SEIU 1199 Connecticut) Jerome Brown raises concerns about the Washington agreement that parallel those voiced by UHW. He warns that neutrality agreements negotiated as part of broader political partnerships with employers could create "the very antithesis of true rank-and-file unionism" (Thomas, 2007). Brown expresses special doubts about the tendency of these agreements to omit workers from any involvement in organizing and bargaining decisions.

Although SEIU's approach to neutrality has stirred the most controversy, in many respects 
the practices of other unions are actually quite similar. For example, the CWA partnership with SBC/Cingular arguably goes beyond the California nursing homes' template contract, which merely sets basic conditions in advance of negotiations. At Cingular, "As soon as you organize, you go right into the national agreement" (Patrician and Raab, 2007). The neutrality agreement specifies that new units will be covered under the national CWA-Cingular contract as soon as a majority card check is confirmed.

Other union agreements mirror key provisions of the SEIU accords. The UNITE-HERE hotel contracts assure neutrality only at specified properties, and the UAW deal with Daimler-Chrysler only applied to some of the company's U.S.-owned factories. The parallel with the limited applicability of SEIU's nursing home neutrality in California and Washington is obvious.

There certainly are legitimate concerns about whether we can rebuild the labor movement without engaging workers in struggle. One answer to this dilemma is to embrace an approach that combines neutrality with key elements of the grassroots, union-building model. As described by Kan Zinn of the AFL-CIO, "We don't believe in negotiating an alternative process in advance of organizing.... We stress the involvement of the workers in the campaign to get neutrality" (Zinn, 2007).

Although the emphasis and style of organizing may vary, many unions do involve current members in the fight for neutrality. At SBC, the CWA engaged in "several years of grassroots action around card check" to secure member support before reaching agreement with the company (Patrician and
Rabb, 2007). Similarly, UNITE-HERE educated local leaders and activists in advance of 2006 hotel negotiations about the need for neutrality, then relied extensively on volunteer organizers from established locals once neutrality agreements were secured. Including workers from the targeted units in the fight for neutrality appears to be far less common, and in the event that EFCA is enacted the need for this would effectively disappear.

But, is it necessary to engage workers in the campaign for neutrality, or is it sufficient to win their signatures or votes for representation? The position on this question associated with Change to Win unions is that the emphasis should be on securing recognition, thereby increasing density in key markets, which will build workers' power and the leverage to improve wages, benefits, working conditions, and voice.

Ultimately, both the decision to pursue neutrality and the type of agreement negotiated will be determined by some combination of strategic considerations, economic and political leverage, and internal union dynamics. There will always be trade-offs, and no two situations are likely to be identical. To some ex-

\section{When unions win}

\section{employer neutrality, they enhance the potential for organizing success.}

tent, every union will have to decide be-tween the short-term interests of current members and the long-term objective of growth. Every union will also have to weigh the advantages of 
engaging workers in a bottom-up struggle to achieve recognition, against the potential gains offered by opportunities to use top-down approaches to achieve neutrality.

Whatever the tactical decisions of individual unions in specific campaigns, none of the recent discourse around deficiencies in particular agreements alters the core reality-when unions win employer neutrality, they enhance the potential for organizing success. When it makes strategic sense to use grassroots organizing as a component of the campaign for neutrality, it is likely that the new local will be in a stronger position to defend workers on the job. When it is expeditious to rely solely on topdown methods to more quickly secure neutrality and first contracts, the unions will still need to attend to the challenge of mobilizing workers so that representation does not simply become a transitory empty shell. No matter how unions decide to proceed, it is clear that enforceable employer neutrality will continue to be a central component of labor's organizing strategy.

\section{THE CONTINUING QUEST FOR TRUE ORGANIZING NEUTRALITY}

F POLITICAL FORTUNES PAVE THE WAY FOR ENACT-

ment of the EFCA, this indeed would have some potential to benefit labor by establishing a less contentious legal framework. But whatever happens to the law, private sector density will rebound only when unions develop sufficient leverage to win collective bargaining rights from reluctant employers. UNITE-HERE's Hotel Workers Rising Campaign and CWA's card check organizing at Cingular provide high visibility examples that need to be replicated broadly throughout the labor movement. They represent remarkable accomplishments in the context of an extremely unfriendly NLRB and its interpretation of an already weak set of labor laws. Interunion squabbling and fingerpointing aside, all of the ongoing initiatives aimed at securing enforceable employer neutrality are contributing to labor's efforts to discover a path to growth.

Where unions succeed in securing effective neutrality, organizers will be able to turn their attention to building enthusiasm for union representation among workers-a less complex challenge than under the standard NLRB framework because employer resistance is limited. There is no silver bullet, and no substitute for strategic sophistication in union organizing programs. The unions that rise to the challenge of implementing organizational change, exploiting synergies between bargaining and organizing, and building the capacity to secure enforceable neutrality agreements will be in the best position to thrive.

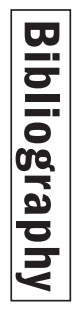

Acuff, Stewart. 2007. Organizing Director AFL-CIO. Personal interview, Washington, DC, June 8.

Adams, Roy J. 2006. "The Employee Free Choice Act: A Reality Check," Labor and Employment Relations Association. Proceedings of the $58^{\text {th }}$ Annual Meeting.

Baird, Orinn. 2007. Associate General Counsel, SEIU. Personal interview, Washington, DC, June 7.

Becker, Craig, James Brudney, Charles Cohen and Joan Flynn. 2006. "Neutrality Agree- ments Take Center Stage at the National Labor Relations Board," Labor Law Journal, v. 57, no. 2, 117-128.

Benz, Dorothee. 2002. "Organizing to Survive, Bargaining to Organize," Working USA, v. 6 , no. 1, 95-107.

Brenner, Mark. 2007. "SEIU Ends Nursing Home Partnership," Labor Notes, June 25.

Bronfenbrenner, Kate and Tom Juravich. 1998. "It Takes More Than House Calls: Organizing to Win with a Comprehensive Union-Building Strategy," in Organizing to Win, edited by Kate 
Bronfenbrenner, Sheldon Friedman, Richard Hurd, Rudolph Oswald, Ronald Seeber, Cornell University Press, 19-36.

Crump, Joe. 1991. "The Pressure's On: Organizing Without the NLRB," Labor Research Review, no. 18, 33-43.

Eaton, Adrienne and Jill Kriesky. 2001. "Union Organizing Under Neutrality and Card Check Agreements," Industrial and Labor Relations Review, v. 55, no. 1, 42-58.

Farmer, Jeff. 2007. Organizing Director, International Brotherhood of Teamsters. Persona interview, Washington, DC, June 7.

Hurd, Richard and William Rouse. 1990 "Progressive Union Organizing: The SEIU Justice for Janitors Campaign," Review of Radical Political Economics, v. 21, no. 3, 70-75.

Moberg, David. 2006. "Paradigm Shift," In These Times, v. 30, no. 2, 41-43.

Moriarty, Joan. 2006. Creating Luxury, Enduring Pain, UNITE-HERE, April.

Patrician, Robert and Kris Raab. 2007. Research Economists, Communication Workers of America. Joint personal interview, Washington, DC, June 8.
Raynor, Bruce. 2006. Public lecture, Cornell University, Ithaca, New York, October 26.

Schmitz, Jim. 2007. Organizing Director American Federation of State, County and Municipal Employees. Personal interview, Washington, DC, June 8.

SEIU United Healthcare Workers West. 2007. The California Alliance Agreement:Lessons Learned in Moving Forward in Organizing California's Nursing Home Industry.

Shaw, Randy. 2007. "Weekly Reaches New Low in Hit Piece on SEIU," Beyond Chron: San Francisco's Alternative Online Daily News, April 16.

Sherwyn, David, Zev Eigen and Paul Wagner. 2006. "The Hotel Industry's Summer of 2006," Cornell Hotel and Restaurant Administration Quarterly, v. 47, 337-349.

Smith, Matt. 2007. "Union Disunity," San Francisco Weekly, April 11.

Thomas, Ralph. 2007. "Union, Nursing Home Alliance Teams Up," Seattle Times, March 20.

Zinn, Ken. 2007. AFL-CIO Director for Strategic Research. Personal interview, Washington, DC, June 8. 